\title{
Sacralizing the Palace, Sacralizing the King: Sanctuaries and/in Royal Residences in Medieval Europe
}

\section{Peter Rietbergen}

Arguably, the ideal as well as the reality of (the concept of) kingship - both in the Judeo-Christian world of the post-Constantinian, later Roman Empire and its successor states, and, indeed, in other, non-Christian polities of Eurasia, too always needed sacralization. Not only through ritual but also through (other) representations, every monarch's subjects had to be impressed with the reassuring fact that the royal person was uniquely positioned to link the natural world to the supra-

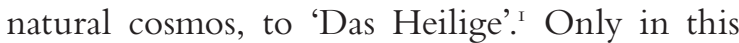
way could people be confident that, through their ruler who, after all, claimed to be God's legitimate representative on earth, the Divine would actually work in their favour: that harvests would produce abundant - or at least: enough - food, that battles would end in, hopefully resounding victories, that the future of the state would be secure because the man and family embodying it succeeded in procreating themselves, et cetera. Therefore, in medieval Europe, royal residences, from the Byzantine Empire to England, from France to Bohemia, had to be more than the dwelling of a mere mortal monarch. If, somehow, they were turned into places wherein the ruler could (re-)present himself in a sacred context, his prestige and status would greatly increase, and so would, consequently, his power. Hence, constructing a sanctuary in the palace was a necessity.

To examine the varieties of the - also architectural and decorative - strategies chosen by Christian kings to achieve this end, I propose to study four somehow interconnected cases: the chapels in Byzantium's Great Palace; the Sainte-Chapelle in the Parisian Palais de la Cité; the Chapel of St Stephen in London's Palace of Westminster; and the two chapels in the great castle-palace of Karlstejn in Bohemia. Analyzing them in chronological order, I hope to show the ways in which these schemes for sacralizing and thus enlarging royal power did resemble and, even, influence each other.

\section{Chapel of the Virgin of the Pharos: Centre of the 'New Jerusalem'}

Crowning the first of the 'seven' hills on which the capital of the Byzantine Empire was built, the palace of the basileus - 'to heiron palation', the 'Sacred Palace' - was a complex that, at least in Europe, remained unequalled both in size and in splendor till its almost total despoliation by fellow-Christians during the Sack of Constantinople (I204). By imperial command, the thirty-something churches, chapels and oratories in the imperial compound also came to house the greatest collection of Christian relics ever assembled in one place.

Tradition has it that Constantine, founding the new capital in and with his name, also wanted to sacralize it with relics of the Church's saints. ${ }^{2}$ Of course, he never could hope to emulate the 'first' Rome; there, Peter and Paul were buried and there the catacombs housed the bones of so many hundreds or, as people liked to believe thousands of other martyrs. And yet! Had not his mother, Empress Helena, presented him with a piece of the Saviour's cross and with one of the nails that had pierced his limbs? Indeed, it was said that these relics were enclosed in the emperor's life-size, gilt-bronze statue on the porphyry column in his new forum. Moreover, Constantine did succeed in bringing to the 'second' Rome the body of Peter's older brother, Andrew, the 'first-called', and of other venerable men and women. His successors added to the collections till, by the ninth century, they filled the city's churches to overflowing. ${ }^{3}$

Outstanding troves of sacred treasure were three of the many sanctuaries within the palace precinct itself - now all destroyed. The first two were the enormous nea ekklesia and the small oratory of St Stephen - since stephanos means 'crown' or 'wreath', it was used for the coronations of, especially, empresses. But despite its 


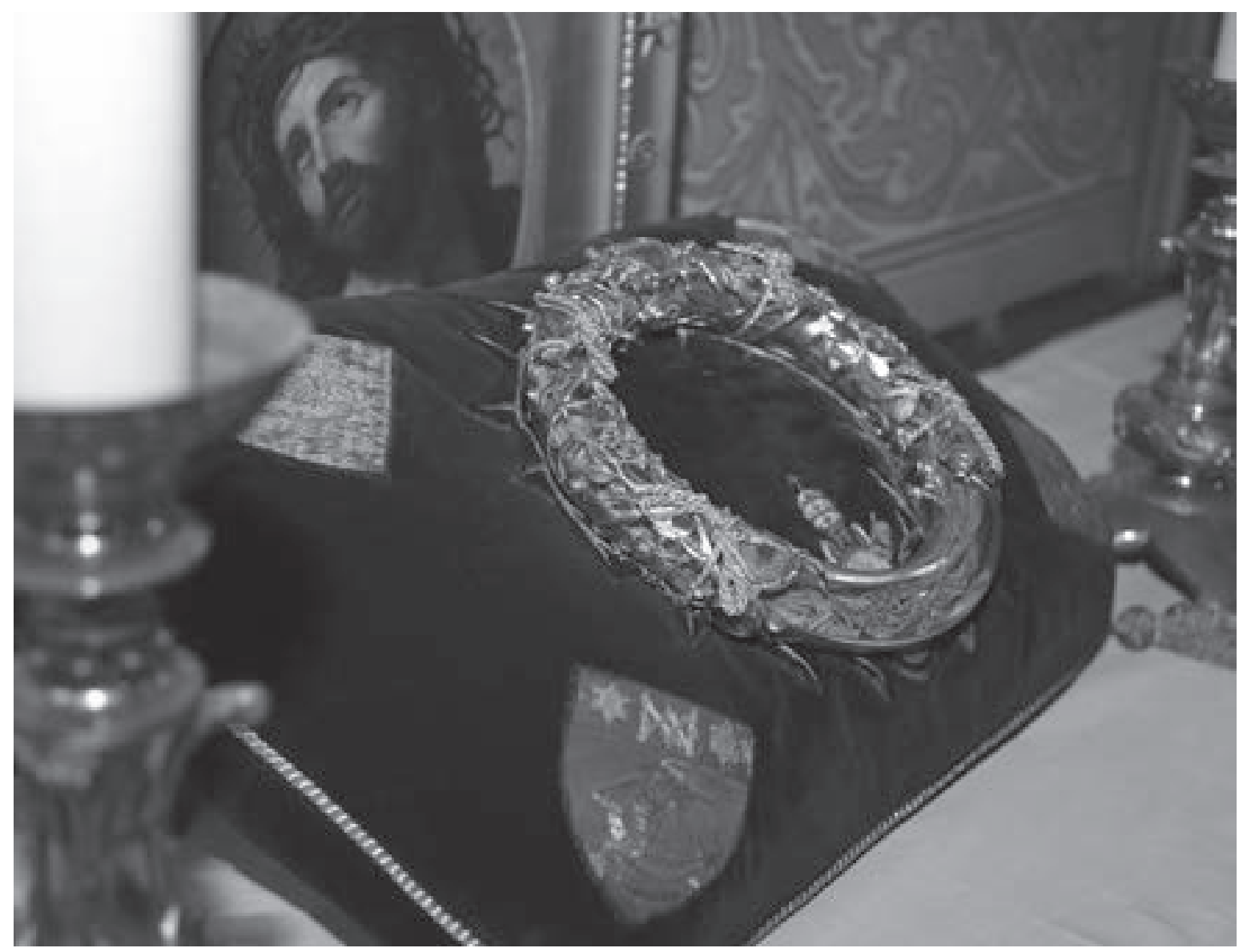

Fig. I. The relic of the crown of thorns, once in the chapel of the theotokos, of 'God's Mother', of the Pharos, in Constantinople, then in the Sainte-Chapelle in Paris, and now in that city's Notre-Dame. Image in the public domain.

relatively modest size, the Church of the Virgin of the Pharos - so-named after its vicinity to the city's famous lighthouse - was the imperial church-reliquary par excellence. ${ }^{4}$ It served to house the many relics from Jerusalem and other places in the Holy Land that from the seventh century onwards were being occupied by Muslim rulers. Their transfer to the imperial capital stimulated the gradual genesis of Constantinople as the 'Second Jerusalem'. Obviously, the new situation helped to stress the role of the basileus as the guardian of Christendom and, indeed, as God's representative on earth.

Actually, the church very much resembled a jewel-casket. According to the, tantalizingly few and incomplete descriptions, part of the walls and the entire ceiling were covered in gold and silver, the altar and the ciborium were of gold, doves hovering above it were set with pearls and emeralds, and all holy vessels were made of precious metals, too. Of course, the church's mosaics must have glimmered as well: Christ looked down from the cupola, surrounded by angels; the Virgin sat enthroned in the apse; prophets, apostles and other saints and martyrs were depicted on the side-walls. Surely, there must have been a few biblical kings, too ${ }^{5}$ - for an opportunity to link the rulers of Byzantium to their Old Testament predecessors in this holiest of holies would have been too good to be missed.

By the end of the twelfth century, the Pharos-Church held a collection of relics linked to Christ's Passion as complete as any believer might wish. Pilgrims from all over the Christian world were shown (parts of) the purple robe and the crown of thorns (Fig. I), the Holy 
Face - the mandylion from Edessa -, the True Cross itself, the Holy Nails, the Holy Lance, the burial shroud, and numerous other items. ${ }^{6}$ Thus, the entire sequence of the Lord's Passion could be re-lived in this space. To even more highlight the relics, most had been put together in what seems to have been a large show-case, its interior entirely set with glass or crystals that constantly reflected the light. It may well have been conceived to emulate the sacred repository in the old Constantinian basilica in Jerusalem.?

No wonder that, according to court ceremonial, Sunday Mass in the Pharos-Church - sung by the imperial eunuchs - was attended by the monarch, his family and high-ranking guests. ${ }^{8}$ Inevitably, during Passion week, the True Cross and the Holy Lance were venerated there by the basileus and his court. When famine or other crises threatened imperial power, some of the relics were carried in procession through the capital, or borne at the head of the army going into battle, to improve morale. ${ }^{9}$ Moreover, the emperors used pieces of these sacred objects as gifts ${ }^{\mathrm{IO}}$ - mostly to strengthen their ties with neighbouring rulers.

Both the astonishing palace and its relic-filled sanctuaries drew the awed admiration of visitors from the West ${ }^{\mathrm{II}}$ - none more so than what they named the 'santa capella', the Church of the Pharos. No wonder then, that during the infamous Fourth Crusade the treasures of the imperial residence and its churches were robbed by soldiers and knights alike, either to ensure their own salvation or for sale to the highest bidder. One of these bidders was the King of France, Louis, the ninth of that name (r. I226-70). Indeed, between I239 and I24I, he seems to have acquired almost the entire content of the Pharos-Church. ${ }^{\mathrm{I}}$

The Sainte-Chapelle: A Reliquary and a DynasticNational Shrine

Power always entails competition. Therefore, relics, as signs of power, are objects of competition. ${ }^{13}$ Might I suggest that Louis, in making his purchases from the Byzantine Empire's spoils, also was motivated by the fact that, precisely in I238-39, the relics of the Virgin kept in the im- perial chapel at Aachen, had been transferred to a sumptuous shrine that, for some time, made it a centre of European pilgrimage again? ${ }^{14}$

However that may be, having, at staggering cost, bought his own relics - it seems that on the crown of thorns alone Louis spent as much as half the annual budget of his kingdom - the king obviously wanted to exploit their religious-political potential to the full. To house this treasure, he decided to build a new SainteChapelle, ${ }^{\mathrm{IS}}$ as the sacred space of his Parisian palace. ${ }^{16}$ In a sense, the Sainte-Chapelle, too, replicated the Constantinian chapel in Jerusalem, as had the Church of the Pharos. ${ }^{17}$ Alas, we know little about the ritual-political use of the relics assembled there. It is, however, clear that on the eve of Good Friday Louis personally took the crown of thorns from 'la grande chasse' - the huge, golden shrine, now lost, of which he alone held the keys - to show it to his court and guests. I feel that in doing so he consciously or unconsciously repeated the ceremony performed by the Byzantine emperors with the relics of the True Cross. ${ }^{18}$ Also, of course, the image of the king holding the crown of thorns on Good Friday must have been a very powerful one indeed. Actually, already in I244, Pope Innocent IV - who desperately needed French support in his struggle with the then Holy Roman emperor ${ }^{19}$ - told the faithful that the French king had been crowned by Christ himself with his crown of thorns.

But to sacralize French kingship Louis had acquired other holy objects as well. Among his purchases of the early I240s was the rod of Moses. Already in Byzantium it had been revered as a symbol of royal power and been preserved in St Stephen's Chapel. Was not Moses the first of the line of God-appointed law-givers, a line that continued with the anointed kings of Israel and culminated in Christ himself? Now the proud possessors of the crown of thorns and the Holy Rod, the French kings could present themselves as the true descendants and rightful heirs of this most august line. ${ }^{20}$

Soon, Louis's chapel, the better part of which was finished in $\mathrm{I} 248$, though primarily serving as a royal oratory acquired the reputation of a national shrine as well. The Sainte-Chapelle 


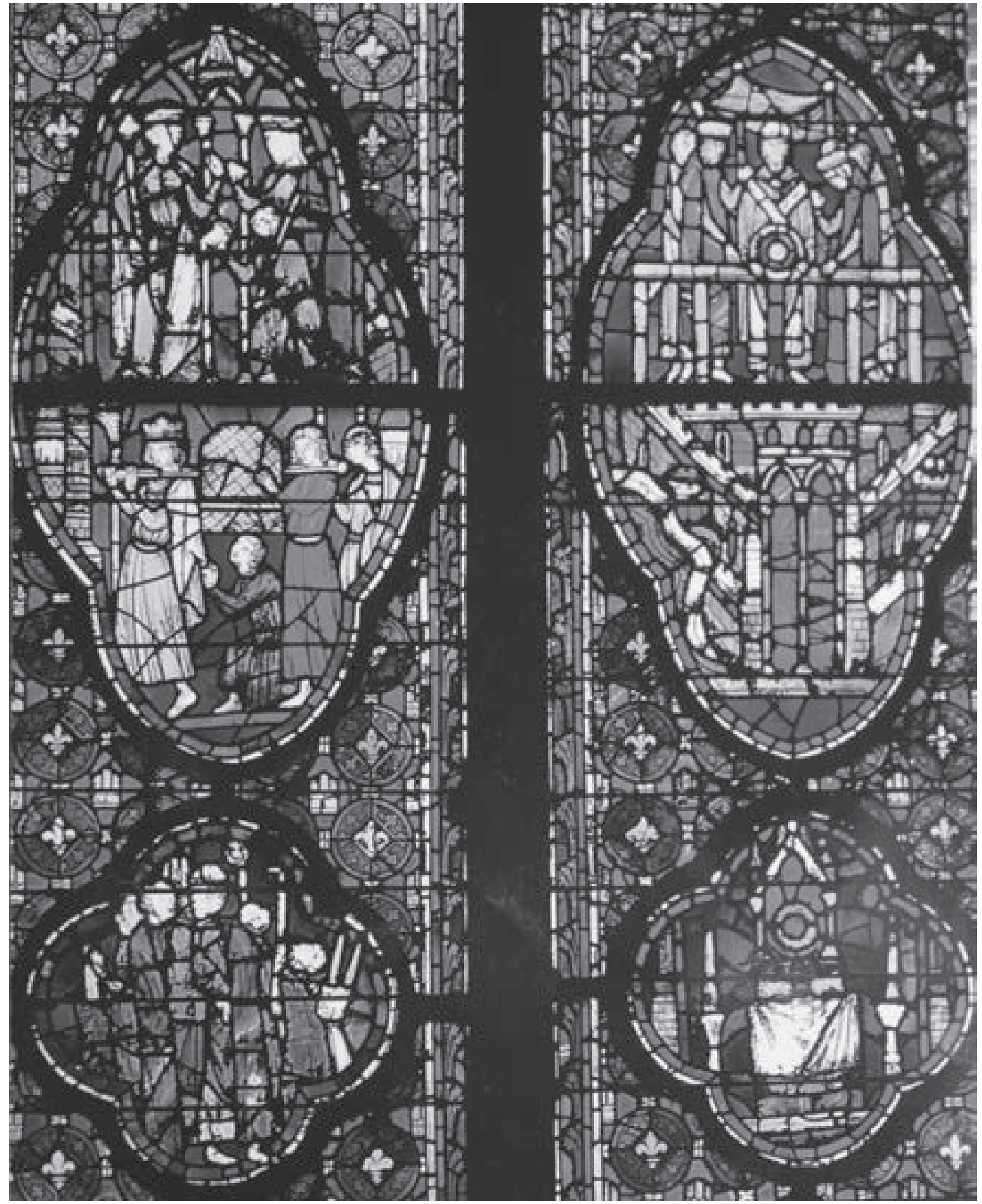

Fig. 2. King Louis and a noble carrying a relic (lower left) and the King and, perhaps, his mother Blanche flanking a priest (upper right), stained-glass window, Paris: Sainte-Chapelle. Image in the public domain. 
became the focus of France as a country favoured by God, ${ }^{21}$ in accordance, surely, with Louis's own dynastic and political wishes. This sacred site and its contents gave the French kings a status more exalted than any other Christian monarch. Indeed, precisely in the later thirteenth century, they began to regularly use the designation 'roi très-chrétien'. ${ }^{22}$ Louis and his successors directly linked their crown, their kingship, to the most holy crown ever, the one that had crowned Christ: a crown, of course, that by that very token was far more sacred than the one used for the coronation of Europe's would-be most important rulers, the Holy Roman emperors. Though the French kings never held the imperial dignity, yet Louis unfailingly presented himself as the equal of its mainly German incumbents: was he not, also, a direct descendant of Europe's first emperor?

Inevitably, deciding to spectacularly sacralize his palace Louis must have remembered the Aachen Chapel of, precisely, Charlemagne ${ }^{23}-$ despite the fact that it was octagonal, following Roman-imperial models, whereas the Parisian building was a two-storey, rectangular construction. In Aachen, Louis's ancestor had sat on his throne in the upper gallery, directly facing the fresco depicting Christ. ${ }^{24}$ In Paris, he himself faced, with his family and other dignitaries, the casket holding the relics of Christ that occupied the apse of the upper chapel.

In a way, the one-nave, very tall Gothic structure of the Sainte-Chapelle mirrors the reliquary in which the sacred objects were preserved. ${ }^{25}$ Indeed, by virtue of its enormous expanse of stained glass - a construction made possible through the ingenuity of the unknown architect, who contrived to hold the stone skeleton of the building together with a metal chain - shines like a jewel-box itself. But the purpose of the windows - undeniably the chapel's most impressive decoration - was not to dazzle the visitor with its many colours. They were designed to emphasize the various roles of royalty. ${ }^{26}$

The programme of the fenestration was conceived - by who(m) is not known - in three registers, showing some IIOO different scenes; part of them are thirteenth- and fifteenth-century originals, part are nineteenth-century re- constructions. ${ }^{27}$ Admittedly, due to the chapel's narrow dimensions, the middle and upper registers hardly can be 'read' by any viewer. However, starting from left to right, and going from low to high, a (biblically) linear story develops, historically beginning with Genesis and ending with King Louis receiving the relics of the Passion (Fig. 2). I only analyse those windows that have an overt royal-propagandistic content.

In the Exodus-window, the exploits of Moses are highlighted, both in giving the law and in governing his people's spiritual life. The window visualizing stories from Numbers again stresses the dual, royal and priestly power of Moses - now aided by Aaron - and does so precisely above the niche where, according to tradition, King Louis would sit when he attended Mass. ${ }^{28}$ In the windows that take their subject matter from Deuteronomy and Joshua, the episodes selected clearly refer to battles against infidels, as prefiguring the Crusades. The Ezekiel-window, too, is used to vindicate Christian politics in the Holy Land, referring to the Prophet's vision of the destruction of Jerusalem after its inhabitants have betrayed their faith.

An inevitable choice was, of course, the Book of Judges, always presented as a manual for the various tasks of Christian kings as well. The window dedicated to the stories of Esther, who saved the Jews from the schemes of the Persian king's evil adviser, obviously points to Queen Blanche (II88-I252), Louis's mother. Not only was her piety much revered, also and far more importantly, as regent of France she had saved the kingdom, both for her son - by putting down the rebellion of the magnates - and for the faith, because she had, in a manner, ended the Albigensian insurrection.

The window that sums up the kingship-related stories from Samuel as well as from I and II Kings precedes the one in which Louis receives the relics of the Passion; alas, the latter mostly is a nineteenth-century re-invention. ${ }^{29}$ Inevitably, the apse-windows show the crucifixion. The biblical ending of the entire sequence is shown in the rose-window that depicts the Apocalypse. In its present state it dates from the fifteenth century but the scene had been part of the original concept already. It suggests that the 
king - again as in the window of Numbers is, really, a priest-king. He and his dynasty will lead France till the end of time.

The Sainte-Chapelle acquired even greater significance when, in I298, Pope Boniface VIII elevated Louis IX amongst the Church's saints, where he joined his two canonized forebears: France's first queen, Clovis's wife Clotilde, who had converted her husband and, hence, France, to Christianity, and the royal family's most famous representative, Charlemagne. Of course, the silver casket in which the remains of the new saint, St Louis, now were held was brought to the chapel, to join the relics of Christ. But the monks who guarded France's royal necropolis at Saint-Denis would have none of it. In the end, however, Philip the Fair did manage to retain at least his grandfather's head for the chapel, thus sanctifying it through yet another relic.

\section{St Stephen's Chapel: A Vision of Plantagenet \\ Future}

In London, little remains of the grand complex that was the main residence of the kings of England, though the Houses of Parliament, built in the I850s, occupy its site and still are called 'the Palace of Westminster'. The one medieval building that stands is, of course, Westminster Hall. Till the early nineteenth century it was used for royal banquets and other festivities. Even now it is the setting for the lying-in-state of a deceased royal.

Within the nineteenth-century palace, a splendidly decorated lobby, St Stephen's Hall, harks back - at least in its ground plan, of 29 by 9 metres - to a very important part of the former palace: the Chapel of St Stephen. One of the lobby's very romantic frescoes shows King Edward III (r. I327-77) approving the plans for what was to be his London 'oratory', ${ }^{\circ}$ constructed atop an older chapel dedicated to Stephen, reputedly the first disciple of Christ to die a martyr. Another fresco shows that earliest chapel's founder, the one English king who bore the saint's name, Stephen (r. II35-54).

Alas, Edward's chapel was gutted by fire in I834. Hence, any reconstruction of what some historians have described as one of the major royal and, indeed, dynastic buildings of fourteenth-century England only can be tentative. Luckily, drawings survive, made by antiquaries and other scholars prior to the chapel's final demolition..$^{3}$

Edward's foundation, begun in the early I330s and finished only in the early I360s, was a two-storied construction, with the, older, lower part accessible to a wider public and the newer, upper part reserved for the royal family and their immediate entourage. This choice obviously and without any doubt consciously referred to the Parisian Sainte-Chapelle, ${ }^{32}$ built by Edward's great-great-grandfather, the sainted Louis; indeed, the measures of the new London chapel almost exactly matched the Parisian one. However, though the new sanctuary retained the name of the older one, neither St Stephen nor his kingly namesake were given a role, there. Actually, the two statues that adorned the new east front showed St John and, more significantly, St Edward (r. I043-66), 'the Confessor', ${ }^{33}$ from whom Edward himself took his name.

Whereas the lower chapel - heavily restored in the late nineteenth century and now known as the Chapel of St Mary Undercroft - was a shrine to the Virgin, whose statue stood there, ${ }^{34}$ the upper chapel did not become a reliquary, as its Parisian prototype. Though the English kings owned one of the realm's largest relic collections, including a thorn from the famous crown and a piece from the famous cross, none of these objects were permanently transferred to the oratory, but mostly remained in the royal treasury in the Tower. ${ }^{35}$ Therefore, I do not agree with those scholars who feel that Edward wanted to create an exact English version of the French shrine..$^{36}$ But what, then, did the now vanished upper chapel try to convey?

My study of the accounts that document both the construction and the sumptuous decoration taught me that it was adorned with sculpture certainly of angels but perhaps also of biblical kings - and with murals depicting scenes from the Old Testament. All paintwork, including that on the statues, was done in oil - for which the artists received expensive brushes of various kinds - and, moreover, partly gilded. Indeed, the amount of gold-leaf supplied to the decora- 


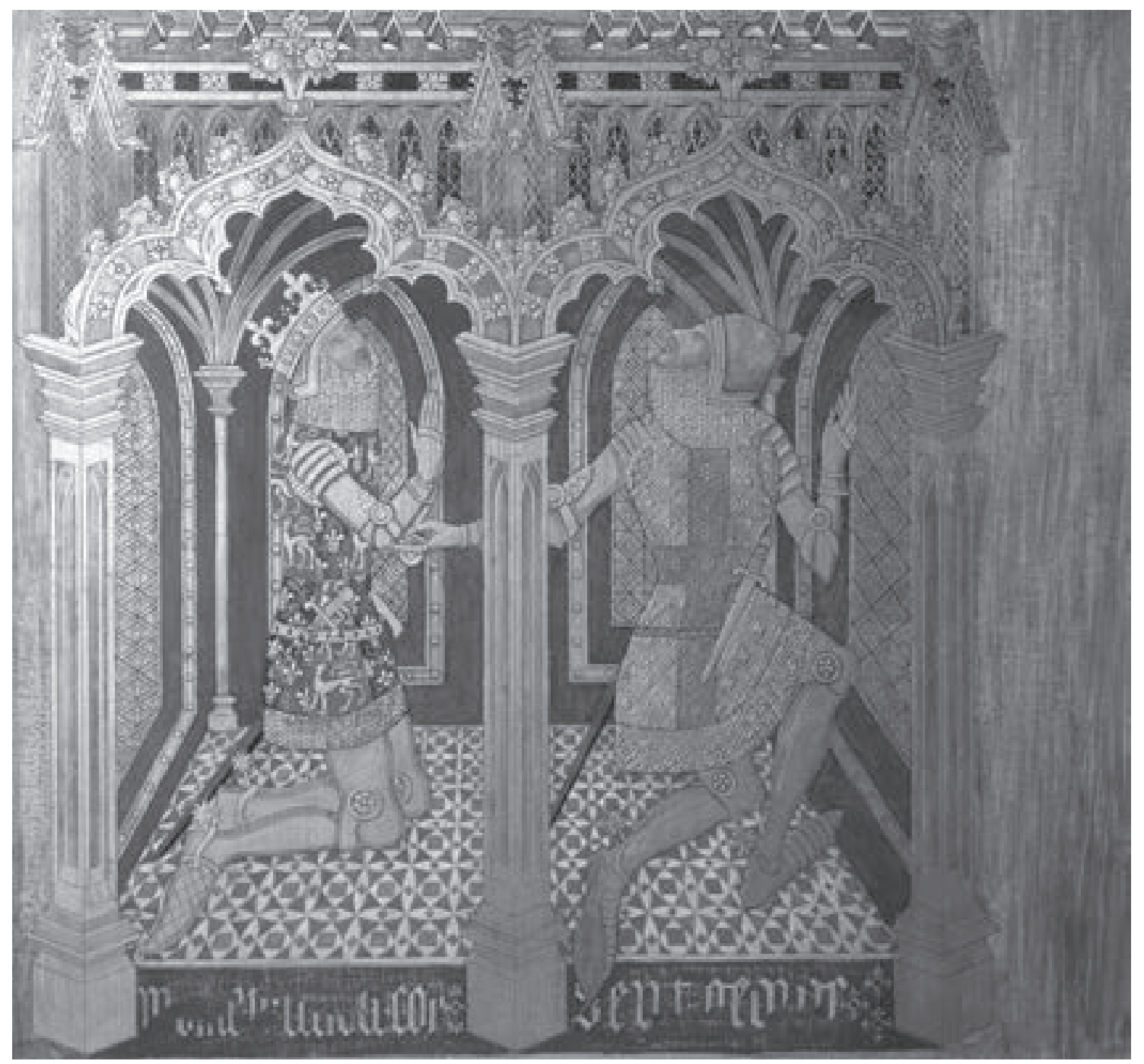

Fig. 3. Reconstruction of the frescoes on the altar wall showing St George and King Edward III, Westminster: St Stephen's Chapel. Image in the public domain.

tors over the years must have cost a fortune, for gold covered the better part of the walls as well. The windows were, at great cost, filled with coloured glass: blue, red, white, yellow. ${ }^{37}$ But it is the pictorial decoration of the arcades under the huge window that adorns the East, or altar wall that really shows the meaning the king wanted to give to his new foundation.

Already during his life-time, Edward - famous for his very public display of 'personal' piety, shown both in extravagant gifts to sundry churches and monasteries all over his realm and abroad, and in untiring pilgrimages to numerous sacred sites - was likened to the usual
Old Testament kings, to Charlemagne and, of course, to that uniquely English monarch, Arthur. ${ }^{38}$ However, despite this impressive albeit fictive ancestry, given England's tumultuous recent past the king may have feared for the future of his dynasty. The Canons of St Stephen's were ordered to say offices daily, both diurnal and nocturnal, and till eternity, for the king himself, his wife, and, significantly in view of the chapel's altar murals, for his potential successors.

Those visitors who looked east beheld a series of frescoed scenes that definitely presented a royal, religious-political programme. In the lower register, on either side of the altarpiece 
that probably showed the Virgin and Child, all male and female members of Edward's family were portrayed in the full splendour of fourteenth-century knightly and courtly apparel. Thus, the Plantagenets genuflecting in reallife prayer watched themselves do so in paint, too. Moreover, the canons who daily prayed for their masters' salvation always faced them as well.

On the left hand, England's national saint, St George, dressed in contemporary royal garb, beckons the king and his five sons Edward, Lionel, John, Edmund, and little Thomas, to adore the Virgin and her child variously depicted in the upper register (Fig. 3). On the right hand, the very popular Queen Philippa, daughter of the count of Hainault, Holland and Zeeland, and her four daughters, Isabella, Joan, Mary, and Margaret, look upward, too, though, seemingly strangely, not induced to do so by another intercessory saint. What we actually are shown is the entire royal family - as it were embodying the English people - being led to salvation by the nation's patron. At the same time, the murals give proof of the royal couple's felicitous fecundity that, if anything, secured both the family line as well as, thus, England's survival from potential succession wars. In short, a hoped-for future is stressed rather than, as in many such depictions of royals, a hallowed past.

The theme of legitimation becomes even more clear in the murals that constitute the altar wall's upper register. They represent scenes from the Nativity episode, specifically the Adoration of the Shepherds and of the Three Magi. Now, one or more of the latter traditionally were linked to the French royal line ${ }^{39}$ - and Edward, of course, was French both on his mother's side, as well as, in multiple ways, through his grandfather and grandmother. He also is known to have been a lavish gift-giver especially on the feast of the Epiphany..$^{40}$ Thus, the frescoes link the Plantagenets to the birth of Christianity as well as show, through that link, the legitimacy of their rule.
The Chapel of the Holy Cross: The Seal of the Imperial Dignity?

Arguably, Charles - originally Wenzel - of Luxemburg (1316-78), King of Bohemia, was one of Europe's most interesting fourteenth-century monarchs, both in his political astuteness, that mixed realism with idealism, tradition with modernity, and in his cultural achievements, that were many indeed..$^{41}$ Having been elected King of the Romans in 1346 and, again, I349, he yet awaited his imperial coronation, which took place in Rome in I355 and made him the fourth Holy Roman emperor bearing the name of Charles. Facing, as all emperors did, opposition both from within and without, he needed to show Christendom that he was, by divine order, its most exalted prince. ${ }^{42}$

Around the time of his coronation, Charles seems to have decided to start rebuilding the stronghold of Karlstejn, some 35 kilometres from his Bohemian capital Prague, with the specific aim of making it the crowning symbol of his imperial dignity. As part of his dwellingquarters on the castle's second terrace, in I357 a chapel was founded. In it, the Virgin, to whom it is dedicated, is depicted with the emperor and the empress at her side; an adjoining small oratory honours St Catherine, and again shows Charles and his wife. Part of the chapel frescoes, finished in the 1360 , tell the story of the House of Luxemburg. In one of the scenes, the emperor is given relics by his Byzantine colleague, John V Palaiologos - not every sacred object had been stolen in $\mathrm{I} 2 \mathrm{O} 4$ !

Interestingly, in another fresco Charles is given or sold some thorns from the famous crown by the French king (Fig. 4). ${ }^{43}$ Actually, the emperor had received part of his early education in Paris, where he had been entertained at the 'Palais de la Cité' and, undoubtedly, been awed by the Sainte-Chapelle. Its memory as well as his own growing treasure of sacred relics may well have inspired the construction, in the main tower on the third and highest of the castle's terraces, of a chapel meant not only to safeguard as well as show off that collection, which included fragments of the True Cross, but the invaluable imperial insignia, too, with, of course, the 


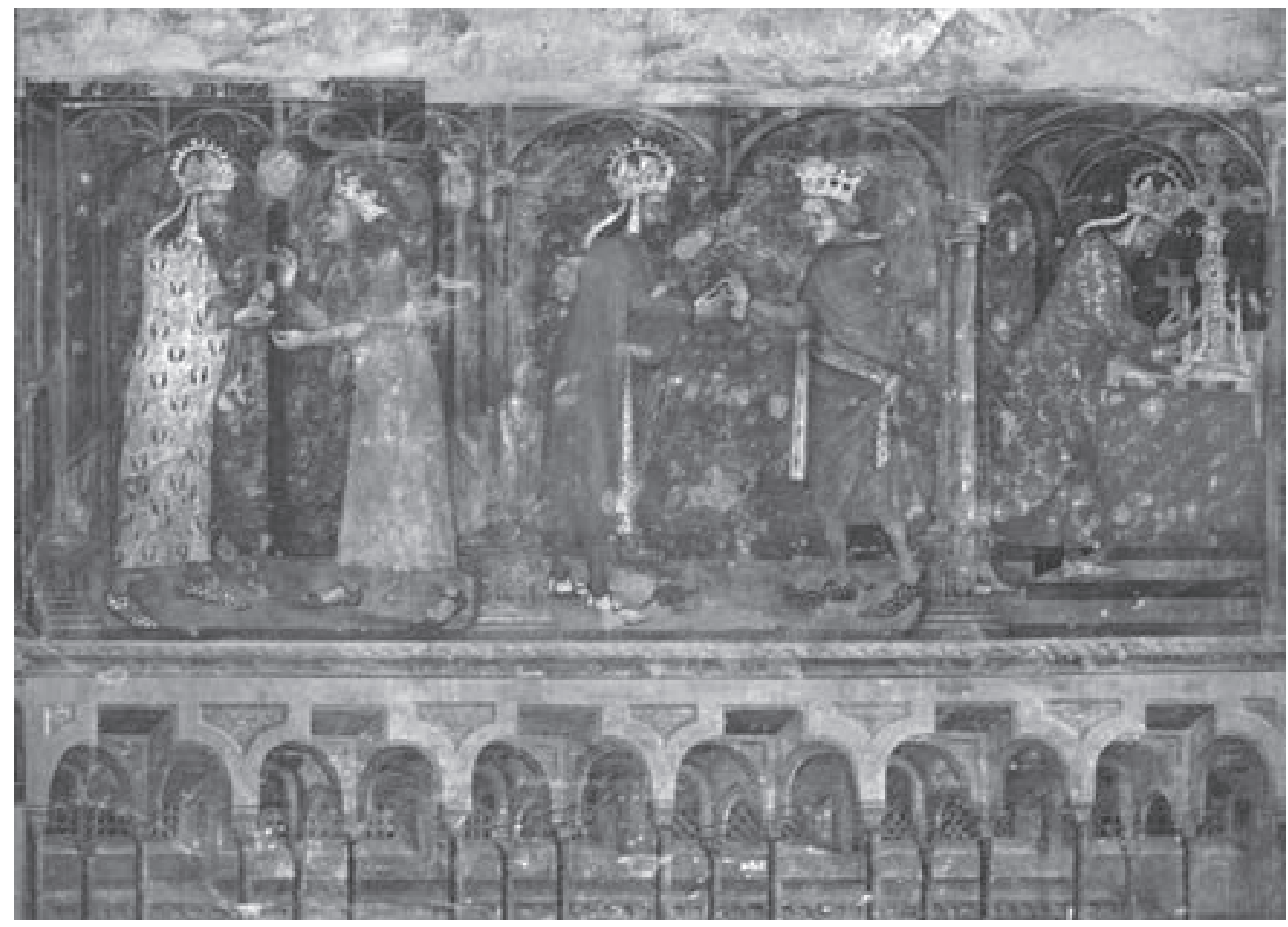

Fig. 4. 'Translation' of relics and, hence, of power: Christ's relics go from Byzantium to France, and from France to Emperor Charles who finally deposits them in his chapel: series of frescoes, finished i36os, Karlstejn Castle, Chapel of the Virgin. Image in the public domain.

so-called 'crown of Charlemagne', used for the imperial coronation, as its most significant and legitimizing item.

Actually, the major parts of the tower were all about legitimation, albeit in a sometimes convoluted way. In the stairwell that winds up to the new 'Heilig-Kreuz-Kapelle', the legend of St Ludmilla (860-92I), Bohemia's first Christian queen is shown. She was the grandmother of King Wenceslas (907-35), Bohemia's patron saint who also was Charles's name saint. Charles must have felt himself lucky in being able to point to such saintly forebears, thus emulating his French relatives with their saints in their Parisian chapel. Interestingly, Wenceslas is represented as a second Christ - but showing the facial features associated with Charles. Indeed, Charles was the first European prince consistently to use socalled 'identification portraits', that were meant to impart the ideal characteristics of a saint to the person who lent him his face. ${ }^{44}$

The decoration of the Holy Cross Chapel - also founded in 1357 but only consecrated in 1365 - probably dates from the early I360s as well. Its cross vaults are covered in gold incrusted with Venetian glass and with gems to resemble the heavens with sun, moon and stars. The small window-panes were made of amethyst and rock-crystal. On the lower walls, even nowadays amethysts, cornelians and other semi-precious stones form a multitude of crosses. ${ }^{45}$ Lit, as the chapel once was, by three huge crystal chandeliers, now lost, and by more than 1300 candles, ${ }^{46}$ it must have resembled the jewel-like Chapel of the Pharos even more than the royal chapels in Paris and London. 


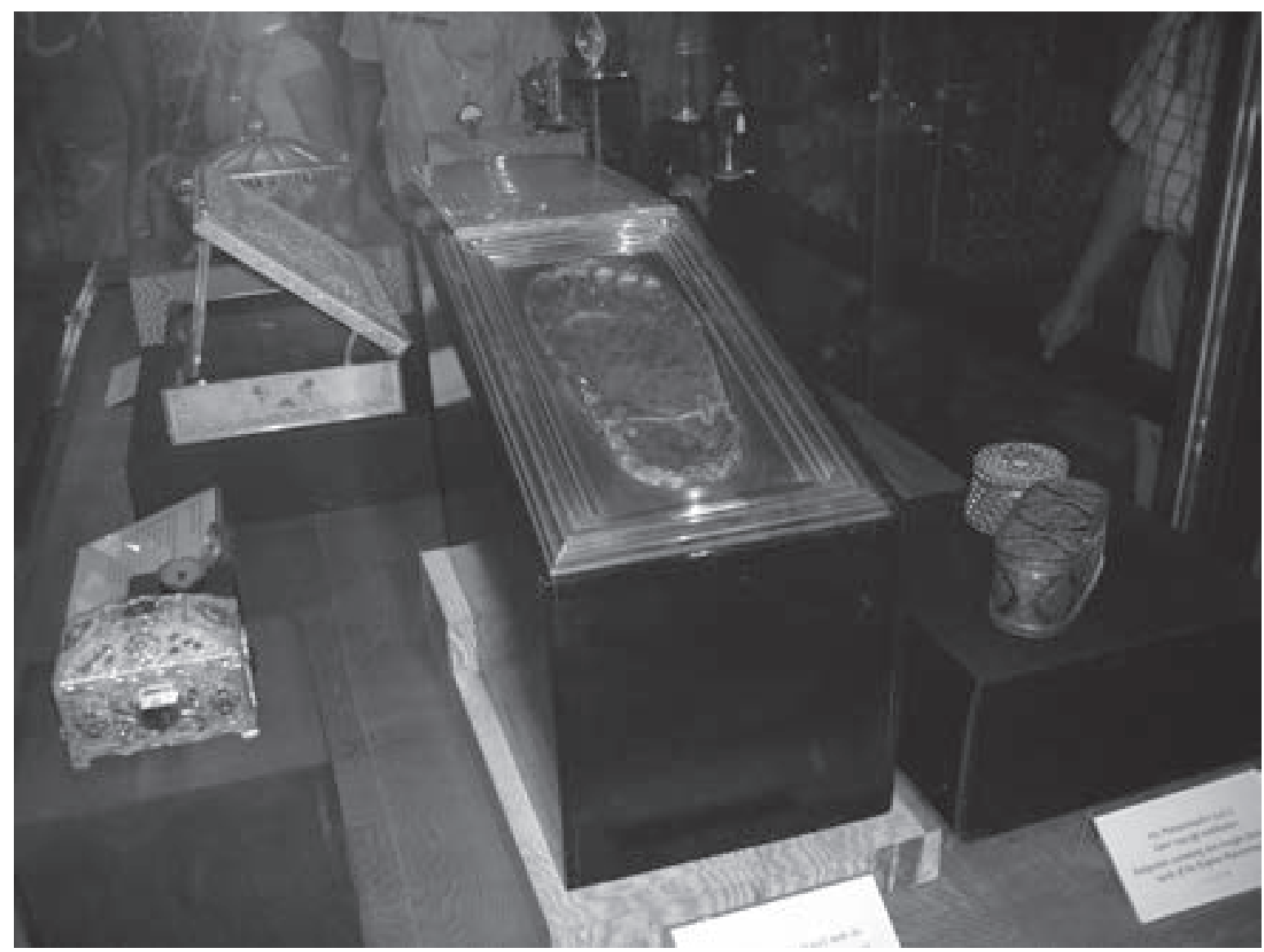

Fig. 5. Exhibition of the relics of the Prophet amongst which his hair, teeth, and a print of his foot, in the 'relic rooms', Istanbul: Topkapi Palace. Image in the public domain.

The chapel walls' upper reaches, however, are truly unique in that they show a series of 129 portraits on wooden panels set in stucco, all considered the work of a rather elusive albeit idiosyncratic artist, one Master Theoderic, Charles's court painter, ${ }^{47}$ and his helpers. Though, then, the panels do not in themselves narrate a story, their sequence yet provides the biblical context for the central scene above the altar, that, of course, shows the Crucifixion. Besides the close entourage of Christ - Mary, Joseph, the disciples, the evangelists, et cetera - numerous saints are depicted, some of them with the features of living contemporaries as well. Several portraits were pierced to allow the insertion of the relics associated with the person depicted. Thus, the chapel surrounded the faithful on earth with all the blessed and holy inmates of heaven - a worthy place, as an inscription on one of the doors had it, for Christ to return to on the Youngest Day.

Not surprisingly, Charles himself is shown as one of the Magi. Actually, the emperor often resided in Cologne where the cathedral was, of course, Europe's major shrine of the three kings - some of whom, as indicated above, were used by various European royals as their mythical ancestors or, at least, exemplars.

Not surprisingly, either, Charles also ordered the portrayal in the chapel of his real forebear, Charlemagne, whose name he had taken and whose imperial title was the crowning glory of his life. Indeed, Charles did hold very specific ideas about imperial power. In his so-called 'Golden Bull' of I356, which regulated imperial elections and formulated imperial aspirations and quite probably was influenced by such texts as Dante's De monarchia, popes - holy or 
not - did not figure. Inspired by the Holy Spirit, without any intervention or sanction by the Roman pontifex, the electors would choose a caesar-augustus to rule the temporal 'imperium' directly under God.

We do not know what ceremonies were enacted in the Karlstejn chapel. Yet all who saw the emperor praying before Christ crucified, amidst pieces of Christianity's holiest relics, surrounded by images of Old Testament kings and New Testament saints, and in full view of the jewel-encrusted imperial insignia must have been convinced that Charles was, as he wanted to be, God's plenipotentiary, the one and only vicarius Dei.

\section{Palaces and Kingship Sacralized}

The four cases presented above show the variegated ways in which Christian monarchs sought to and succeeded in sacralizing their palaces. Employing a variety of means - architectural and decorative, but also ceremonial and ritual - they created sacred spaces that greatly

\section{Notes}

I The concept famously was coined by Rudolf Otto, Das Heilige (Munich: Beck, I9I7).

2 Holger A. Klein, 'Sacred relics and imperial ceremonies at the Great Palace of Constantinople', in Visualisierungen von Herrschaft, ed. by Franz Alto Bauer (= $B Y Z A S, 5$ (2006)), pp. 75-99; cf. also his: 'Constantine, Helena and the early cult of the True Cross in Constantinople', in Byzance et les reliques du Christ, ed. by Jannic Durand and Bernard Flusin (Paris: Association des Amis du Centre d'Histoire et Civilisation, 2004), pp. 3I-59.

3 Raymond Janin, La géographie ecclésiastique de l'Empire byzantine, part I, III: Les Églises et les Monastères (Constantinople) (Paris: Institut français d'études byzantines, I969); Jean Ebersolt, Sanctuaires de Byzance: Recherches sur les anciens trésors des églises de Constantinople (Paris: Leroux, I92I).

4 Paul Magdalino, 'L'Église du Phare et les reliques de la Passion à Constantinope', in Byzance et les reliques $d u$ Christ, pp. I5-30; about the chapel's pre-eminence: Romilly Jenkins and Cyril Mango, 'The date and significance of the tenth homily of Photius', Dumbarton Oaks Papers, 9-Io (1955-56), I23-40.

5 Alexei Lidov, 'A Byzantine Jerusalem: The Imperial Pharos Chapel as the Holy Sepulchre', in Jerusalem as Narrative Space, ed. by Annette Hoffmann and contributed to their own status and power. Admittedly, whereas first the Parisian and subsequently the Karlstejn chapel achieved 'sacrality' primarily through important relics that once had enhanced Byzantium's imperial pretences, thus differing from the chapel in Westminster Palace - though there, too, parts of the Holy Cross seem to have been exhibited every now and then - the major function of all three spaces was to visually represent dynastic aspirations in a religious context.

Fascinatingly, after the Fall of Constantinople in I453, the 'Sacred Palace' whose relic-shrine had inspired Europe's Christian monarchs yet influenced the representational repertoire of another line of rulers, the conquering Ottomans. Not only did they built their own imperial residence on its site, within it they constructed a 'chapel' as well, to house the Prophet $\mathrm{Mu}-$ hammad's relics brought there to sacralize the sultan's dwelling and, thus, his power. Significantly, amongst these, was the rod of Moses... But the story of these objects is another one altogether (Fig. 5). ${ }^{48}$

Gerhard Wolf (Leiden: Brill, 20I2), pp. 63-IO3; esp. pp. 7I-73.

6 E.g. the list in : Krijnie N. Ciggaar, 'Une description de Constantinople traduite par un pelerin anglais', Revue des Etudes Byzantines, 34 (I976), 2 I I-67.

7 Lidov, 'A Byzantine Jerusalem', pp. 78-80.

8 Ibid., pp. 70-7I.

9 Ioli Kalevrazeou, 'Helping Hands for the Empire: Imperial Ceremonies and the Cult of Relics at the Byzantine Court', in Byzantine Court Culture from 829 to 1204 , ed. by Henry Maguire (Washington DC: Dumbarton Oaks, I997), pp. 53-79. Also, despite its idiotic title: Sophia Mergiali-Sahas, 'Byzantine Emperors and Holy Relics: Use, and Misuse of Sanctity and Authority', Jahrbuch der Österreichischen Byzantinistik, 5I (200I), 4I-60.

Io Lidov, 'A Byzantine Jerusalem', p. 69.

I I Michele Bacci, 'Relics of the Pharos Chapel: A View from the West', in Eastern Christian Relics, ed. by Alexei Lidov (Moscow: Progress-tradition, 2003), pp. 234-48; cf. also: Holger Klein, 'Eastern Objects and Western Desires: Relics and Reliquaries Between Byzantium and the West', Dumbarton Oaks Papers, 58 (2004), 283-3I4.

I 2 Jannic Durand, 'La translation des reliques impériales de Constantinople à Paris', in Le trésor de la Sainte- 
Chapelle, ed. by Jannic Durand and Marie-Pierre Lafitte (Paris: Réunion des musées nationaux, 200I), pp. 37-II2; cf. also: Daniel Weiss, Art and Crusade in the Age of Saint Louis (Cambridge: Cambridge University Press, I998).

I3 Edina Bokozy, La politique des reliques de Constantin à Saint Louis: protection collective et légitimation du pouvoir (Paris: Beauchesne, 2007) provides a general survey.

I4 Der Aachener Marienschrein, ed. by Dieter Wynands (Aachen: Einhard, 2000).

I5 Jean-Michel Leniaud and Françoise Perrot, La SainteChapelle (Paris: Centre des monuments nationaux, 2007).

I6 On the palace: Herveline Delhumeau, Le Palais de la Cité: Du Palais des rois de France au Palais de Justice (Paris: Cité de l'Architecture et du Patrimoine 20I I).

I7 Matthias Müller, 'Paris, das neue Jerusalem? Die Ste-Chapelle als Imitation der Golgatha-Kapellen', Zeitschrift für Kunstgeschichte, 59 (1996), 325-36.

I8 Klein, 'Sacred relics', pp. 89-9I.

I9 Elie Berger, Saint Louis et Innocent IV: Essais sur les rapports de la France et du Saint-Siège (Paris: Thorin, I893).

20 Elizabeth Hallam, 'Philip the Fair and the Cult of Saint Louis', Studies in Church History, I8 (I982), 2OI-I4.

2I Alyce Jordan, Visualizing Kingship in the Windows of the Sainte-Chapelle (Turnhout: Brepols, 2002), and Beat Brenk, 'The Sainte-Chapelle as a Capetian Political Program', in Artistic Integration in Gothic Buildings, ed. by Virginia Chieffo Raguin and others (University of Toronto Press, I995), pp. I95-2II.

22 Colette Beaune, Naissance de la nation France (Paris: Gallimard, I985), p. 287.

23 Inge Hacker-Sück, 'La Sainte-Chapelle de Paris et les chapelles palatines du moyen age en France', Cahiers archéologiques, I3 (I969), 2I7-57. See also the contribution of Bianca Kühnel in this volume.

24 Peter Rietbergen, Karel de Grote (Amersfoort: Bekking \& Bliz, 2009), pp. 7I-72.

25 Robert Branner, 'The Grande Châsse of the SainteChapelle', Gazette des Beaux-Arts, 77 (I97I), 5-I8.

26 For the following, besides my own interpretation: Jordan, as well as: Claudine Billot, 'Le message spirituel et politique de la Sainte-Chapelle de Paris', Revue Mabillon, 2 (I99I), II9-4I.

27 Part of the chapel's exterior and interior sculpture (including the altar) as well as the painted decoration are nineteenth-century, and mostly inspired fantasies.

28 Leniaud and Perrot, pp. I36, I93.

29 Ibid., p. I8I.

30 The term was used in the fourteenth century; see the documents published by: Edward Brayley and
John Britton, The History of the Ancient Palace and Late Houses of Parliament at Westminster (London: Weale, I836), p. I59.

3 I Emily Howe, 'Divine Kingship and Dynastic Display', The Antiquaries Journal, 8I (200I), 259-303.

32 Maurice Hastings, St Stephen's Chapel and Its Place in the Development of the Perpendicular Style in England (Cambridge: Cambridge University Press, I955), pp. 64-65.

33 Brayley and Britton, p. I57.

34 Ibid., p. I80.

35 William M. Ormrod, 'The Personal Religion of Edward III', Speculum, 64 (I989), 849-77 (p. 873).

36 Ibid., p. 856.

37 Brayley and Britton, pp. I70, I73, I8I sqq, I84.

38 See the numerous examples cited in: Political Poems and Songs Relating to English History, ed. by Thomas Wright, I (London: Longman, Green Longman, and Roberts, I859).

39 Paul Binski, Westminster Abbey and the Plantagenets: Kingship and the Representation of Power, 1200-1400 (New Haven and London: Yale University Press, I995), p. I83.

40 Howe, n. III.

4I Kaiser Karl IV: Staatsmann und Mäzen, ed. by Ferdinand Seibt (Munich: Bayerisches Nationalmuseum, I978; repr. 2003); Iva Rosario, Art and Propaganda: Charles IV of Bohemia, 1346-1378 (Woodbridge and Rochester, NY: Boydell and Brewer, 2000).

42 Michael Lindner, 'Es war an der Zeit: Die Goldene Bulle in der politischen Praxis Kaiser Karls IV', in Die Goldene Bulle: Politik - Wahrnehmung - Rezeption, ed. by Ulrike Hohensee and others (Berlin: Akademie, 2009), pp. 94-I4I.

43 Older texts identify the frescoes rather differently: Franz Auge, Beschreibung der Burg Karlstein (Prague: [n. pub.], I8I9), p. II.

44 Robert Suckale, 'Die Portraits Kaiser Karls IV als Bedeutungsträger', in Das Porträt vor der Erfindung des Porträts, ed. by Martin Büchsel and others (Mainz: Von Zabern, 2003), pp. I9I-204.

45 Karl Möseneder, 'Lapides vivi: Über die Kreuzkapelle der Burg Karlstejn', Wiener Jahrbuch für Kunstgeschichte, 34 (I98I), 39-70.

46 Auge, p. I9.

47 Jiri Fajt and Jan Royt, Magister Theodoricus, Hofmaler Kaiser Karls IV. Die künstlerische Ausstättung der Sakralräume auf Burg Karlstein (Prague: Národní Galerie v Praze, I997).

48 Peter Rietbergen, 'Not of this World? Religious power and imperial rule in Eurasia, c. thirteenthc. eighteenth century', forthcoming. 